\title{
Institutional Shortfalls and a Political Crisis
}

\section{Anne Cussac}

\section{(2) OpenEdition}

\section{Journals}

Electronic version

URL: https://journals.openedition.org/eastafrica/731

DOI: 10.4000/eastafrica.731

ISSN: 2790-1076

\section{Publisher}

IFRA - Institut Français de Recherche en Afrique

\section{Printed version}

Date of publication: 1 April 2008

Number of pages: 259-286

ISSN: 2071-7245

\section{Electronic reference}

Anne Cussac, "Institutional Shortfalls and a Political Crisis", Les Cahiers d'Afrique de l'Est / The East

African Review [Online], 38 | 2008, Online since 18 July 2019, connection on 09 December 2021. URL: http://journals.openedition.org/eastafrica/731 ; DOI: https://doi.org/10.4000/eastafrica.731

This text was automatically generated on 9 December 2021.

Les Cahiers d'Afrique de l'Est / The East African Review 


\title{
Institutional Shortfalls and a Political Crisis
}

\author{
Anne Cussac
}

1 Only a few days after he announced the controversial results of the 2007 presidential election, Samuel Kivuitu, chairman of the Electoral Commission of Kenyan (ECK), acknowledged making the declaration under joint pressure from Mwai Kibaki's Party of National Unity (PNU) and Kalonzo Musyoka's Orange Democratic Movement-Kenya (ODM-K) and said on 1January 2008: "I don't know whether Kibaki won the election." Because of its suspected involvement in rigging, the ECK therefore appeared to be among the main culprits in the political crisis.

2 After the opening of the democratic space and the reintroduction of the multi-party system, a number of reforms had been made to enhance independence and capacity of the electoral commission. But these structures were merely based a gentleman's agreement, and were not entrenched in the law, the only way of ensuring strong legal backing. Similarly, there exists a whole legislative framework designed to guarantee free and fair elections and to deal with possible petitions that may arise after the announcement of election results. However, the rules of the game and the weakness of institutions charged with implementing these measures proved to be a limiting factor in the ECK's effectiveness. Evidence also revealed practices aimed at making the ruling party all-powerful and, apart from the political crisis and of the violent clashes that ensued, the controversial 2007 December elections not only uncovered a number of institutional shortcomings, within not only the electoral commission, but also within the judicial system and the Kenyan political system at large.

\section{Electoral commission at the centre of controversy}

3 Although the ECK had always been accused of not carrying out its duty with impartiality, its good performance was recognized for the first time during the 2002 polls which was marked by a smooth political transition. Nevertheless, during the entire 2007 campaign period, one of the big questions was the Commission's ability to 
guarantee free and transparent elections. While we agree that it satisfactorily presided over campaigns and the voting exercise, the manner in which S. Kivuitu declared M. Kibaki's re-election as president cast doubt on the commission's credibility and the commissioners' independence from the government.

\section{Questions over the unilateral appointment of electoral commissioners}

4 The existence of the ECK is in accordance with Articles 41 and 42 of the Constitution, which stipulate that its responsibility shall be to organize and oversee the electoral process. ${ }^{2}$ In theory, with regard to Article 42 (a) of the Constitution stipulates that its functions, which include: "(a) registration of voters and maintenance and updating of the voters' roll; (b) manage and supervise independence, the institution must not be under the authority of any other organ." ${ }^{3}$ Commissioners are appointed by the President for five years and its Chair and Vice-Chair must be qualified to be judges of the High Court. Evidence shows that until in the 1990s, the jurisdiction of ECK commissioners was confined to defining borders of electoral constituencies, while the other organizational roles were the responsibility of the provincial administration and the Supervisor of Elections. However, as the 1992 general elections approached, the Election Laws Amendment Act No. 1 was passed and this position was abolished and all powers of the Commission were restored. Justice Richard Chesoni was appointed Chairman of the ECK, which then consisted of 11 commissioners, all appointed by Daniel arap Moi. ${ }^{4} \mathrm{He}$ officially announced the general elections date later that year, a prerogative that had hitherto been the President's. ${ }^{5}$ In spite of these apparent reforms, the whole of the 1992 election campaign period was marked by opposition concerns over the institution's lack of independence. Oginga Odinga, M. Kibaki, Johnstone Makau and David MukaruNg'ang'a initiated a petition to press for the removal of R. Chesoni, who was considered to be President Moi's man. ${ }^{6}$ Their fears were confirmed during the campaigns and the voting process: the ECK appeared to be in favour of KANU and could neither guarantee free and fair elections nor prevent rigging.

5 A few years later, as the 1997 elections approached, the Inter Parliamentary Parties Group (IPPG) negotiations led to the adoption of a body of reforms that would guarantee a more democratic government and establish a freer and more level political playing field. This was followed by the repealing of a number of laws restricting civil liberties (the freedom of assembly and the freedom of association or expression) and an agreement increased the number of ECK commissioners to $22 .{ }^{7}$ Justice R. Chesoni, whose integrity had been questioned on several occasions and who had been replaced by S. Kivuitu as Commission chairman, was appointed Chief Justice. This spoke volumes of the government's willingness to reform the judiciary. ${ }^{8}$ Furthermore, the IPPG agreement stipulated that half of the ECK commissioners would be nominated by the opposition, even though they would still be appointed by the President. ${ }^{9}$ M. Kibaki played an important role then in putting pressure on D. arap Moi. His party, the Democratic Party (DP), also proposed names of three commissioners among the ten new faces nominated by the opposition..$^{10}$ Thus, the composition of the ECK ahead of the 2002 elections was no reason for major concern. D. arap Moi made seven new appointments to replace commissioners whose term had expired and renewed the terms of the rest of the commissioners, particularly the ten who had been nominated 
by the opposition in 1997. Similarly, the Commission Chairman and the Vice-Chairman were retained in their positions. However, the integrity of some of the commissioners remained in doubt, especially after a delegation led by S. Kivuitu paid a courtesy visit to State House in February 2002 to meet President Moi. Since the group only comprised commissioners appointed by KANU, other ECK commissioners as well as members of the opposition saw it as a political visit ahead of elections. However, the doubts faded away after M. Kibaki's victory.

6 In 2007, the term of office of 22 ECK commissioners expired before the election date and one of the issues that arose was whether M. Kibaki would renew their terms to ensure preparations for elections and the voting exercise were handled by experienced people. Many of those who had assumed new commissioners would be appointed expressed concern over whether the IPPG arrangements would be respected. However, on 12 January, despite mounting pressure from members of the Orange Democratic Movement (ODM) for the letter and spirit of the agreement to be respected, Mwai Kibaki drew battle lines by unilaterally replacing commissioners with new appointees. ${ }^{11}$ In October, with less than two months to the elections, the terms of more commissioners expired, and M. Kibaki replaced Gabriel Mukele as ECK Vice-Chairman on the $12^{\text {th }} .{ }^{12}$ Still without consulting at all with the opposition, he went further to appoint five new commissioners on the $27^{\text {th }}$, and renewed the terms of two others. ${ }^{13}$ The only concession he made was to re-appoint S. Kivuitu chairman of the Commission on 2 December..$^{14}$ Indeed, the ODM led by R. Odinga had intensified pressure, saying that free and fair elections would only be guaranteed by retaining S. Kivuitu as the ECK chairman. The majority of the commissioners were by all standards inexperienced, since only three of them (S. Kivuitu, K. Muttu and J. Tumwa) had presided over an election before.

7 Of particular concern was that whereas the commissioners appointed to preside over the 2007 election had all been appointed or reappointed by President Kibaki, the Commission could be suspected of working in his favour. Some of the appointments, considered as partisan, raised questions about the independence of several commissioners from the executive. For instance, K. Muttu was a former lawyer of the Kibaki family, ${ }^{15}$ while Muturi Kigano had been M. Kibaki's personal lawyer at one time and Pamela Mwikali Tutui was married to a PNU candidate for the Kajiado Central parliamentary seat. The renewal of K. Muttu's contract and his elevation to Vicechairman's position at a time when G. Mukele was being retired raised doubts over the criteria followed in renewing or not renewing some commissioners' terms of office. The letter and spirit of the IPPG agreement ahead of the 1997 elections had been to establish an electoral commission that would represent both the government and the opposition, in order to guarantee its independence and to give it more credibility. However, the IPPG was only an agreement in principle and the law was never amended to entrench its provisions. As a result, since the Constitution still made the appointed of ECK commissioners an exclusive prerogative of the President and there was no provision to seek legal redress if the letter and spirit of the agreement was not respected, M. Kibaki was free to choose to honour or not to honour it. This is why the manner in which ECK commissioners were appointed is considered one of the main explanations for its involvement in rigging. 


\section{The commission's failure to guarantee free and fair elections}

One of the less known functions of the Electoral Commission is the creation of new constituencies. However, such responsibility is first and foremost one of the powers of Parliament, "all constituencies must be as equitable as possible in population, as far as deemed practical by the Commission" (Article 42 of the Constitution). In 1963, 117 constituencies were instituted based on recommendations of the Kenya Constituencies Delimitation Commission chaired by S. Foster-Sutton. In 1966, 41 new ones were created before going up to 188 in 1986 and then finally increasing to the current total of 210 before the 1997 elections $^{16}$. However, at least 12 of the last constituencies were created for political reasons-to increase KANU's chances in Parliament, without considering the principle of equal representation of all citizens and most notably, the ECK did not object. ${ }^{17}$ The law states that the number of constituencies should be reviewed every 10 years in view of population growth. That is why, in December 2007, the ECK proposed the creation of new constituencies, giving Parliament the justification that some constituencies that were heavily populated (Embakasi, Kasarani, Lang'ata) ${ }^{18}$ had the same number of representatives as others that were vast but were populated by less than 50,000 people, as it is the case in the north-eastern parts of the country. ${ }^{19} \mathrm{~S}$. Kivuitu therefore suggested the creation 60 new constituencies. However, several parliamentarians objected to mandating the ECK to proceed, saying that the independence of the Commission was doubtful and expressed fears that they would be created in pro-Kibaki areas to enable his party to have more seats in parliament. ${ }^{20}$

9 Nevertheless, the most important role of the ECK is to organize elections. During the elections that followed the first multi-party elections in 1992 and also in 1997, the institution was heavily criticized for its inability to prevent double voter registration or the transportation of voters across constituencies. In contrast, its work was praised in 2002. For example, in its report on the 2002 general elections, the European Union said that "the ECK and its staff were well- equipped and in general appeared well formed" ${ }^{21}$. For the first time, vote counting was conducted at every polling station rather than at the constituency level, as was the case before..$^{22}$ This new arrangement clearly made the counting more transparent. Even though some cases of negligence were reported in the voter registration process, vote counting was considered well-organized and well conducted. ${ }^{23}$ Following the 2002 elections, the International Commission of Jurists even presented S. Kivuitu with the jurist of the year award for his accomplishment in promoting democracy. The award was also meant to serve as an incentive to encourage him to continue with his role of guaranteeing fair and impartial elections. In the same way it was praised for overseeing successful transitional elections, the ECK was congratulated for the manner in which it presided over the November 2005 constitutional referendum. The two voting exercises also served as examples of speedy announcement of results that were announced less than 12 hours after the polling stations closed. Despite everything, the ECK still suffered from some limitations. During by-elections held in Marsabit, Moyale and Nakuru in 2007, it could not prevent the corrupt practices and the polls were not conducted in a satisfactory manner, according to the Commission's own admission. ${ }^{24}$ Thus, as the 2007 general elections approached, some questions lingered over its ability to guarantee a well-conducted vote.

10 In the period leading up to the 2007, the Commission certainly played its role rather well. As far as its responsibility to conduct voter registration and keeping of voter 
registers was concerned, the ECK already had a total of 12.5 million voters in its roll by end of 2006, and went on to organize several drives to register new voters up to October 2007. At the end of this exercise, it announced a total of 14.5 million registered voters, with a record number of new voters, particularly the youngest adults. ${ }^{25}$ Nevertheless, the enthusiasm with which Kenyans registered to vote should not conceal the fact that some irregularities had been noted. For example, in the month of July, S. Kivuitu expressed concern that the number of voters in some districts was higher than the number of identity card holders, which led to suspicions that there were cases of "importation" of voters who had registered in certain areas whereas they lived elsewhere ${ }^{26}$. A few months later, in October, S. Kivuitu announced that close to 400,000 voters had been registered twice. ${ }^{27}$ Thus, the Commission Chairman was trying to ensure that it was more in charge of the registration exercise and was safe from any political manipulation. However, these revelations only served to create lingering doubts on the ability of the institution to guarantee proper elections.

During campaigns, the commission again tried to show its commitment by punishing several parliamentary candidates for incitement to violence. ${ }^{28}$ Similarly, even with the multitude of political parties in the contest, ${ }^{29}$ it successfully managed to print ballot papers (of course through a tender awarded to a company based in the United Kingdom) and to dispatch election materials to polling stations in different parts of the country, albeit with a few incidents..$^{30}$ On the voting day, several centres, particularly in Nairobi, Kisii and Narok opened late, but the ECK allowed voting to continue beyond the initially scheduled closing time to allow citizens to exercise their right to vote. There was also a mix-up of ballot papers involving various polling stations (ballot papers for Lenchami and Ilpolosat in the Kajiado North constituency were found in Changamwe, Coast Province). The problem was resolved, however, by airlifting the correct ballot papers, which occasioned just a slight delay in the opening of the affected polling stations. Finally, in Lang'ata, the Nairobi constituency where R. Odinga voted, the registers with names starting with letters "A," "O" or "R" were missing on voting day. Luo names mostly start with an " $\mathrm{A}$ " or an "O." ${ }^{31}$ But the ECK Chairman went to the affected area in person to resolve the problem and R. Odinga as well as the other people affected by the unfortunate event were able to fulfil their civic duty.

The ECK's image was therefore tarnished after the controversial declaration that M. Kibaki had been re-elected. This was due to confusion that surrounded the announcement and the cloud of doubt that hung over S. Kivuitu's power over the Commission and its members. Indeed, at one moment while the results were still being awaited, he had intimated that he could not reach some commissioners by telephone nor did he even know where several of them were. ${ }^{32}$ On 30 December, in particular, as S. Kivuitu announced the presidential poll results for some constituencies late in the afternoon, the results were contested by W. Ruto, an ODM agent, leading to protests at the Kenya International Conference Centre (KICC) hall, where announcements were being made. Members of the police force entered the room and evacuated S. Kivuitu, who a few hours later announced the re-election of M. Kibaki as president of Kenya in a room where only journalists of the national broadcaster $\mathrm{KBC}$ had been allowed. One hour later, the President was sworn at State House in by Chief Justice, Evan Gicheru. The ECK lost all credibility and has been accused of supporting the Kibaki side by approving fraudulent results. In this case it was even more criticized because there is a whole body of rules to guarantee transparent counting and tallying of votes. 

for the presidential poll, indicating the total number of votes garnered by every candidate), 16A (on the declared results of the parliamentary poll and the presidential poll by constituency) and Form 17A (on the results of parliamentary and presidential polls by constituency), which by obligation must be signed by the officer and the various political party agents. Furthermore, agents, the media and international observers can obtain and keep copies of these documents, which are then sent to the ECK headquarters in Nairobi. Upon reception, any candidate can ask the electoral commission for a re-count or a re-tallying-a request that cannot be turned down. Therefore, when S. Kivuitu announced M. Kibaki's victory, even as ODM members requested for a recount in some constituencies, he did not observe electoral law. The credibility of the ECK was further tarnished, after M. Kibaki's contested re-election, when four commissioners (J. Tumwa, Daniel Ndambiri, Samuel arap Ng'eny and Jeremiah Matagaro) said they had serious doubts about the tallying of votes. ${ }^{33}$ In conclusion, the ECK proved completely incapable of ensuring the results of the presidential poll were authentic after three days had gone by following the end of the voting exercise and the declaration of the new President. Doubts persist over validity of the results announced by the commission. The accusing finger may have been pointed at the ECK as the institution responsible of the chaos that followed M. Kibaki's reelection, ${ }^{34}$ but the crisis also highlighted the diminished credibility of the judiciary.

\section{An independent judiciary in theory}

After the swearing-in of a president, the law stipulates that decision to hold a fresh election can only emanate from a High Court ruling. Nevertheless, R. Odinga, who contested the legitimacy of M. Kibaki's election, refused to file any petition in court, questioning the little of independence of the judicial system. From that point of view, S. Kivuitu's confession that: "I arrived later at State House to deliver the certificate and found the Chief Justice there, ready to swear in Kibaki" ${ }^{35}$, (which implied that the Chief Justice ready swear in M. Kibaki even before the official announcement of his re-election), also raises a lot of questions on the autonomy of this arm of government ${ }^{36}$.

In legal and neutral principle, proceedings before the courts are also political insofar as judges make their decisions within a specific political context. However, the judiciary in Kenya has always faced accusations of being close to the executive power and being extremely corrupt. ${ }^{37}$ After the 2002 transition, one of the stated objectives of the Kibaki government had been to put an end to the judicial system's bad image, which it considered as an obstacle to its efficiency. As testimony to his determination, M. Kibaki begun by replacing Chief Justice Bernard Chunga, who was accused of abuse of office, by Evan Gicheru. Furthermore, the Government appointed a Committee on Integrity and Fight against Corruption within the Judiciary in Kenya. The commission was charged with preparing a report on the state of corruption within the Judiciary. According to the document prepared by the commission, known as the Ringera Report $^{38}$, corruption affected $56 \%$ of judges of the Court of Appeal, $50 \%$ of High Court judges and $32 \%$ of magistrates. ${ }^{39}$ It particularly questioned the integrity of five of nine appellate judges, 18 out of 36 High Court judges, 82 magistrates out of a total of 254 as well as 43 other civil servants in judiciary. President Kibaki proceeded to name two tribunals whose mission would be to inquire into these allegations. A number of people 
whose integrity had been questioned chose to retire or resign, but a non negligible proportion decided to respond and raised legal issues against these accusations. Among the cases that eventually came before the two tribunals, only one was concluded with the acquittal of Justice Waki in late 2004.

In spite of the "purge," the independence of the judiciary from the executive appears even more theoretical than real and, in spite of his stated will to change this state of affairs, M. Kibaki has been suspected of partisan appointment of new judges. In 2003 and 2004, the President proceeded to appoint 28 new judges of the High Court in replacement of the accused members of the bench. However, a number of issues have been raised over the criteria of appointment, which are suspected to be more based on political, sectarian and even tribal considerations rather than merit. These appointments have been cited by some critics as proof that "the judiciary has been ethnicized." The critics argue that a majority of the new judges are Kikuyu, M. Kibaki's ethnic community. ${ }^{40}$ Furthermore, rather than enhance independence of the judiciary, the anti-corruption operations and the new appointments once again brought to light the control the executive wields over the judiciary and gave currency to the impression that High Court judges are very often "thanked" for favours to the system. ${ }^{41}$ This lack of independence proved to be blatant in February 2007, after the annulment of the appointment of three High Court judges. In theory, the recruitment and promotion of members of the bench is the responsibility of the Judicial Service Commission (JSC), which makes recommendations to the President. ${ }^{42}$ But after these judges were recruited, influential personalities in the Kibaki administration are said to have pressed for the annulment of their appointment, arguing that the decision to appoint them was made without consultations within political and government circles..$^{43}$ This case showed that the Government was keen to throw its weight on matters affecting the judiciary and the JSC, and thereby reopened the issue of judicial independence. The separation of powers appears to be more than limited insofar as the President exercises control over the judiciary through powers to appoint and dismiss the Attorney-General and the Chief Justice. This explains why ODM has consistently stated its reluctance to seek legal redress, arguing that the judiciary is in the hands of the PNU and going as far as saying that M. Kibaki's appointment of High Court and Appellate Court judges shortly before the vote aimed to counter the possibility of a petition to contest the results.

Besides, even though in electoral matters any voter, candidate or the General Attorney can file a petition to the High Court to contest the result of a vote, the delays in determining the petition are extremely long owing to the backlog in courts and also because the set period for hearing and determining suits is unlimited. ${ }^{44}$ In addition, parliamentarians often take advantage of the shortcomings within the system to delay rulings since legal loopholes allow them to obtain dismissal of cases against them. From a more concrete point of view and as an example, after the general elections 2002, more than 20 petitions were filed, five of which had not been determined by 2007 and one of which only led to a ruling to hold a fresh election... that was held in May 2007 just as campaigns for fresh general elections were picking up. ${ }^{45}$ In February 2003, Julius Daraka Mbuzi filed a petition against the December 2002 election of Harrison Garama Kombe, MP Magarini (in Coast Province), on the grounds that ballot papers used in the voting process were at the time of the vote defective and that various cases of fraud had been committed on the voting day. ${ }^{46}$ The High Court judge in Mombasa, J. Khaminwa, annulled the result of the election then, but her ruling was followed by two appeals, one by Harrison Kombe and the other by the ECK. In March 2006, the Court of Appeal in 
Nairobi dismissed the appeals in two different rulings and a fresh election was held in May 2007 only seven months to fresh general elections. ${ }^{47}$ The result was the re-election of H. Kombe.

18 In the specific case of presidential polls, there are precedents that leave a lot to be desired as far as efficiency in the courts is concerned. In 1992, Kenneth Matiba disputed D. arap Moi's election in the first multi-party election ${ }^{48}$ on grounds of fraudulent results, as well as violence and intimidation by KANU. However, due to a flimsy technical "error"-the petition was not signed by K. Matiba himself but by his wife, the case was dismissed. Several parliamentary election results were also contested but most of the petitions were never determined. ${ }^{49}$ In an irony of history, Mr. Kibaki also contested D. arap Moi's re-election in $1997 . .^{50}$ The High Court also dismissed this petition on technical grounds that D. arap Moi had not been duly served with the court summons in person. Given such precedents, it seemed understandable that R. Odinga rejected the court option, especially because the ODM had won the majority in Parliament and President Kibaki found himself in an unprecedented position. The election of M. Kibaki, who found himself up against a majority of opposition MPs in parliament, revealed the shortcomings of the Kenyan political model.

\section{Discredited political model despite election of a new parliament}

19 The controversy surrounding the announcement of the presidential poll results obscured the outcome of the parliamentary vote, which largely indicated the replacement of MPs with new ones and a situation where the President did not have a favourable majority behind him for the first time in Kenya. Out of a total of 210 elected, the ODM, led by R. Odinga, won 99 seats whereas the PNU, led by M. Kibaki, only got 43 seats. ${ }^{51}$ Furthermore, the parliamentary elections resulted in the fall of a big number of political veterans and M. Kibaki allies, thereby demonstrating their aspirations for change.

Following the vote, only 80 MPs were re-elected. As a result, the 10th Parliament has 130 new faces of which women are a sizeable number..$^{52}$ The 2007 parliamentary poll results are significant in two ways. It reflects a rejection of Moi's old guard and the older generation ${ }^{53}$, and secondly, it reflects a "class struggle" which manifests itself in the wave of change and the rejection of most of Kibaki's former ministers. First, it is certain that the 2007 elections was a litmus test for D. arap Moi's influence following the failure of his "Uhuru project" in $2002^{54}$ and following the increased weakening of KANU, the party he had dominated during his 24 years as Kenya's head of state. ${ }^{55}$ During the entire campaign period, D. arap Moi tried to influence the Rift Valley voters, exhorting the Kalenjin community to vote for M. Kibaki. However, right from the start he had to contend with a younger generation that had coalesced around William Ruto, who was intent on winning to his side voters who had not forgiven M. Kibaki for sacking many members of their community from plum government positions. Besides, the Kibaki government remained very unpopular in the region because it had carried out evictions in Narok, Chepyuk and Mt Elgon areas, in particular, rendering numerous families homeless. A combination of these factors led to M. Kibaki's defeat in the Rift Valley despite D. arap Moi's support. ${ }^{56}$ With a number of former high-ranking Kalenjin civil servants who had worked under his regime rebelling against Moi, the former 
President's influence seemed be declining. The election results in the Rift Valley are thus rather paradoxical because several ODM candidates were influential officials in the KANU government: Henry Kosgey, William Ruto, Franklin Bett, Sally Kosgey (head of the Public Service under D. arap Moi), Kipkalya Kones (former minister) and Zakayo Cheruiyot (former Permanent Secretary in D. arap Moi's government). Furthermore, D. arap Moi's stranglehold on the region was no longer as firm as it was in the past. This was demonstrated by the defeat of his three sons: Gideon in Baringo Central, Jonathan in Eldama Ravine and Raymond in Rongai. Similarly, all his allies in the province lost their seats beginning with controversial Nicholas Biwott..$^{57}$ The former president's popularity is today limited to the Rift Valley political and economic elite, as well as to the Tugen community, a Kalenjin subgroup to which he belongs. In contrast, W. Ruto now appears to be the best placed to represent the region's leadership as he enjoys support from the youth and the poor as well as of the Nandi (to which he belongs) and the Kipsigis sub-groups.

21 The parliamentary elections were also a testimony of the will to punish the Kibaki Government because 22 ministers lost their seats. All M. Kibaki could do was note the defeat of his allies Simeon Nyachae, in the Kisii region, Raphael Tuju, in Nyanza Province, Musikari Kombo and Mukhisa Kituyi, in Western Province, Kipruto Kirwa, in the Rift Valley, Morris Dzoro and Suleiman Shakombo in the Coast Province. Some of them were even party leaders, like M. Kombo, Ford-Kenya chairman, S. Nyachae, FordPeople leader, and R. Tuju, Narc-Kenya leader. ${ }^{58}$ Even in Central Province, the defeat of the "Mount Kenya Mafia" (some of M. Kibaki's allies), was a testimony of an antiGovernment vote. ${ }^{59}$ Considered as "hardliners" because of their approach to national policies, particularly on the issue of constitutional review, these close allies of M. Kibaki represented the most radical wing of the Government and they paid for the failures of the regime, especially in the fight against corruption. Many parliamentarians also paid the heavy price because they had changed their political affiliation or because they had called for the "Yes" vote in the constitutional referendum, when the draft constitution had been rejected in their region. Moody Awori, outgoing vice-president, ostensibly lost his seat because he broke ranks with the LDP, the party that sponsored him to Parliament, to support the draft constitution, which was unpopular in his region. ${ }^{60}$ Furthermore, in Western Province, one of whose constituencies he represented in Parliament, the elections marked a change of leadership following the defeat of $\mathrm{M}$. Kombo, M. Awori and M. Kituyi, ${ }^{61}$ and ushered in new "heavy weights" in the region, Musalia Mudavadi (Sabatia) and Cyrus Jirongo (Lugari). ${ }^{62}$ This development was due to the fact that for the first time the region voted almost unanimously for ODM as opposed to 2002 when even though it had supported NARC, KANU retained a number of seats. ${ }^{63}$ Therefore, the Kibaki camp's strategy of promoting its candidate's re-election by supporting Ford-K in Western ${ }^{64}$, KANU in the Rift Valley and Ford-P in the Kisii region, failed to work.

Following these results and despite the overhaul of the political class, often in favour of newcomers, there were lingering uncertainties on the loyalty of a number of newcomers in ODM. These new faces could have been tempted to follow the example of political opportunism set by ODM-K and K. Musyoka, vice-president in the new Cabinet unveiled by M. Kibaki on 7 January 2008. Moreover, by-elections to fill vacancies occasioned by the murder of two ODM MPs, the election of Emuhaya MP Kenneth Marende as Speaker of the National Assembly and the cancellation of results in three constituencies could have tilted the numerical balance in Parliament. ${ }^{65}$ Similarly, the 
leaning of members of the smaller parties that had won 35 parliamentary seats combined ${ }^{66}$, could have changed the equation of numerical strength in Parliament, especially since the legal framework for the formation of coalitions and the change of political affiliation were not very strict. In theory, in the event that MPs changed parties after their election to Parliament, their seats would become vacant and byelections would be held.$^{67}$ For example, in 1966, when several MPs left KANU to join Oginga Odinga's Kenya People's Union (KPU), by-elections were held in the affected constituencies. However, more recently, in order to deal with divisions with NARC that had brought him to power, M. Kibaki had appointed members of opposition to the Government of National Unity (GNU) ${ }^{68}$ and most MPs elected on the NARC ticket in 2002 changed their political affiliation without their seats being declared vacant. ${ }^{69}$ Though this manoeuvre caused uproar, there was no legal nor constitutional provisions against it, especially since Article 16 of the Constitution provides that the President can appoint any Member of Parliament to the cabinet. However, faced with this controversy, Parliament had passed the Political Parties Bill and an amendment to the National Assembly and Presidential Election Act (Chapter 7 of the Laws of Kenya.) ${ }^{70}$ Thus, Article 17 of the Act now provides that no parliamentarian elected on the ticket of a particular party can accept to be appointed to the Cabinet without the written consent of the leader of his/her party. In case of violation of this provision, the affected parliamentarian will be considered as having resigned from his/her party. ${ }^{71}$ In reality, the sanction was minimal since under the Ninth Parliament, the Speaker of the National Assembly, Francis ole Kaparo was quite flexible in his interpretation of the Constitution, ruling that only a written resignation indicated a change of party. This is why ODM candidate K. Marende's election as Speaker of the National Assembly in January 2008 could mark an important departure in this matter. The PNU Government would have needed a Speaker of such a conservative Parliament to interpret the law in its favour. ${ }^{72}$ That is the reason it would have wished to see Francis ole Kaparo reelected. However, not only will Parliament be presided over by a member of the opposition for the first time in the history of Kenya, but the new Speaker said as soon as he took over the office that his priorities would be to see a new Constitution enacted and to promote a more modern and independent Parliament ${ }^{73}$. However, the majority the ODM commands in Parliament was particularly instrumental in enabling it to make its weight felt even more in the negotiations led by Kofi Annan, which, after a difficult start, ended with an agreement. The agreement attempted to balance executive power, which had hitherto been characterized by enormous presidential powers, through amendments to the original Constitution adopted at independence.

In 1963, Kenya indeed opted for a classic parliamentary system, based on the British model, with a Prime minister and a bicameral Parliament. The Constitution did not provide for the position of President, and Jomo Kenyatta took the country's reigns of power as Premier Minister. However, in 1964, a constitutional amendment made Kenya a republic and vested the executive power in a President, who was head of state as well as head of government and commander-inchief of the armed forces. At the same time, the Prime minister's position was suppressed, to make way for the vice-president's position..$^{74}$ In 1967, the Senate was dissolved, ushering in a mono- cameral system, and in 1968, a constitutional amendment introduced the election of the President by universal suffrage. Gradually, the President's powers extended to an extent that he appeared to have no competing centre of power ${ }^{75}$, but the Kenyan presidential system did not become identical to American model in which the legislative and the executive 
are really independent. Thus, "the originality of the Kenyan constitutional system is based on the fact that the presidential institution is built outside a legal mould that is fundamentally parliamentary." 76 Besides, the Kenyan President enjoys a unique status: he/she represents the symbol of national unity, above political parties, but because he/she also has to be an MP, he/she is exposed to party game. ${ }^{77}$ Similarly, the legitimacy he/she enjoys because of having been elected by universal suffrage, in theory, protects him/ her from a censure motion. Indeed, Article 59 of the Constitution accords Parliament the power to pass a vote of no confidence in the Government by a simple majority. However, whereas the mechanism plays a normal role in a parliamentary system, in the Kenyan model, where the President is both head of state and head of government, the passing of such a motion would put into question the independence the President enjoys by virtue of his/her election through universal suffrage, and would amount to a "legal coup d'État." "78 Though this prospect has never materialized, the ODM could have attempted this option to overthrow M. Kibaki given its numerical superiority in the new Parliament. The signing of an agreement between the two protagonists ruled out this possibility and enabled the country to come out of the crisis. The new arrangement, apart from providing for the reintroduction of the Prime minister's position, that would be occupied by R. Odinga, and the sharing of the ministerial positions between PNU and ODM, it would also pave way for reforms, in the least a minimal Constitutional review.

\section{Conclusion}

Even though the agreement signed between the two opposing parties brought hope after the upsurge in violence that affected the country, there are still uncertainties on the future of Kenyan institutions. We do agree that the reintroduction of Prime Minister's position could limit the powers of the President in the current Constitution, but it will be necessary to clearly and precisely define the duties and responsibilities of the premier. Indeed, the agreement provides the Prime Minister with the "authority to coordinate and to supervise the implementation of operations and business of the Government of Kenya." ${ }^{79}$ However, his future relationship with the President and the Vice-President are not very clear, while his place in the executive hierarchy is uncertain. Similarly, though the reconciliation between the two parties seemed to be the only possible way out of the crisis, Kenya today finds itself without a political party leading the official opposition in Parliament, which can also be a source of concern over checks and balances against excesses of the future Government. Finally, the consensus that the political class has now reached on the need for national reconciliation and on the necessity to safeguard the agreement through constitutional amendments must not make Kenyans forget that the crisis also brought into focus a number of other problems related to the fundamental issue of access to and distribution of national wealth, which the country should resolve or risk a repeat of the same events in future elections. 


\section{BIBLIOGRAPHY}

AYWA, F.A., GRIGNON, F. (2001). ‘As Biased as Ever? The Electoral Commission's Performance Prior to Polling Day.' In Marcel Rutten, Alamin Mazrui and François Grignon, Out For the Count. The 1997 General Elections and Prospects for Democracy in Kenya. Kampala: Fountain Publishers (pp. 110-117).

ANDERSON, D. (2003). 'Le déclin et la chute de la KANU. La recomposition des partis politiques dans la succession de Moi (Kenya) ', Politique Africaine, No. 90, pp. 37-55.

BOURMAUD, D. (1988). Histoire Politique du Kenya. Paris, Nairobi: Karthala, CREDU.

GHAI, Y.P., Mc AUSLAN, J.P.W.B. (1970). Public Law and Political Change in Kenya. A Study of the Legal Framework of Government from Colonial Times to the Present. London and Nairobi: Oxford University Press.

RUTTEN, M., MAZRUI, A.M., GRIGNON, F. (2001). Out For the Count. The 1997 General Elections and Prospects for Democracy in Kenya. Kampala: Fountain Publishers.

THROUP, D., HORNSBY, C. (1998). Multi-Party Politics in Kenya. The Kenyatta and Moi States and the Triumph of the System in the 1992 Election. Oxford: James Currey.

\section{Reports}

Electoral Commission of Kenya's (ECK) National Conference on General Elections 2007 on 13-15 March 2007 at Kenya School of Monetary Studies, Nairobi, p. 4, <www.gendergovemancekenya.org/documents /eck focusingonkenya2007elections.pdf> International Commission of Jurists (ICJ), Kenya: Judicial Independence, Corruption and Reform, Genève, 2005, p. 29-30 <www.icj.org/IMG/pdf/kenyareport.pdf>

Justice Enjoined: The State of the Judiciary in Kenya, The Report of the Robert F. Kennedy Memorial Centre for Human Rights, New-York: Robert F. Kennedy Memorial Centre for Human Rights, 1992.

Kenya General Elections, 27 December 2002. European Union Electoral Observation Mission, Final Report. URL: https://aceproject.org/ero-en/regions/africa/KE/Kenya\%20-\%20EU\%20rep02.pdf [archive].

Report of the Integrity and Anti-Corruption Committee of the Judiciary of Kenya, Vol. I (The Ringera Report), September 2003, p. 30-31.

SIHANYA, B. , KICHANA, P. Judicial Reform in Kenya, 1998-2003, Publication of the Kenyan Section of the International Commission of Jurists (ICJ), 2004, no. 1 in the Judiciary Watch Series.

\section{Newspapers}

Daily Nation

The Standard

\section{NOTES}

1. S. Kivuitu announced the results of the presidential poll on 30 December 2007. As justification, he confessed giving in to pressure in order not to be considered a coward. 
However, he would have been considered much more couragious had he weathered the storm and waited to be sure of the results before announcing the winner of the presidential poll. The Standard, 2 January 2008.

2. Article $42(a)$ of the Constitution stipulates that its funtions, which include: "(a) registration of voters and maintenance and updating of the voters' roll; (b) manage and supervise the presidential, parliamentary and civic elections; (c) promote free and fair elections; (d) promote voter education throughout Kenya; and (e) any other function stipulated by the law."

3. The provisions of Paragraph 9 of Article 41 are: "In carrying out its duties under the current Constitution, the Commission may not be subjected to instructions from any person or authority."

4. D. Throup and C. Hornsby (1998), p. 244-245.

5. Ibid., p. 247.

6. This was rejected by the High Court.

7. It is also in 1997 that the Constitution of Kenya (Amendment) Act No. 9 extended the powers of the ECK to make it better equipped to "guarantee free and fair elections" and to "promote voter education throughout the country."

8. Chesoni did not hold the Chief Justice position for long as he died suddenly in September 1999. He was then replaced by Bernard Chunga. R. Chesoni was seen to be fighting corruption when he set up a committee in 1998 led by Justice Richard Kwach to prepare a report on the challenges facing the administration of justice. R. Chesoni himself was, however, suspected of abuse of office, having been accused of receiving money illegally to rule in favour of several businessmen involved in the Goldenberg corruption scandal...

9. According to the IPPG agreement, the government and the opposition were to nominate an equal number of commissioners to ECK (10 apiece) to guarantee free and fair elections.

10. They were John Habel Nyamu, William Mbaya and Kihara Muttu. Out of the other 10 commissioners nominated by the opposition, three came from Ford- Kenya, two from Ford-Asili, one from the Kenya Social Congress and one from the Social Democratic Party.

11. The President appointed Abdi M. Ibrahim, Anne Mwikali Muasya, Felista Naetu Ole Churie, Joseph Hamisi Dena, Joseph Kipruto Sitonik, Luciano Riunga Raiji, Mildred Apiyo Owuor, Muturi Kigano and Samuel Arap Ng'eny new ECK commissioners.

12. He appointed a woman, Pamela Tutui, to replace Mukele.

13. The new commissioners were Samuel Nyanchama Maugo, Shem Sanya Balongo, Rachel Wanjala Kileta, David Alfred Njeru Ndambiri and Daniel Waisiko Wambura. Jack Tumwa and Kihara Muttu had their terms renewed, with the latter becoming the new ECK Vice-Chairman.

14. S. Kivuitu and G. Mukele were nominated to the ECK in 1992. Their term in office as commissioners were renewed in 1997 and S. Kivuitu was then made the Commission Chairman. The term in office was renewed by D. arap Moi before the 2002 elections.

15. K. Muttu, who comes from Nyeri, M. Kibaki's home district, had been nominated by DP under the IPPG agreement.

16. F.A. Aywa and F. Grignon (2001). 
17. Ibid., pp. 116-7. These were Mwingi South, Kaiti, Kuresoi, Eldama Ravine, Gwasi, Uriri, Gatundu North, Mathioya, Khwisero, Sotik, Bura and Wajir North constituencies.

18. Embakasi, for instance, had 558,587 residents and 151,358 registered voters in the 2002 general elections while Lang'ata had 280,238 residents and 111,829 registered voters.

19. Turkana North constituency, which is one of the largest geographically, had only 33,000 registered voters in 2002 . According to S. Kivuitu, it was to be split as its area made the work of a single parliamentarian difficult.

20. The Standard, 29 May 2007.

21. Kenya General Elections, 27 December 2002. European Union Electoral Observation Mission, Final Report, p. 5.

22. The tallying then followed at the polling centre of every constituency.

23. Kenya General Elections, 27 December 2002. European Union Electoral Observation Mission, Final Report, op. cit., p. 33.

24. Electoral Commission of Kenya's (ECK) National Conference on General Elections 2007 on 13-15 ${ }^{\text {th }}$ March 2007 at Kenya School of Monetary Studies, Nairobi, p. 4.

25. Daily Nation, 25 October 2007.

26. Daily Nation, 5 July 2007.

27. Daily Nation, 5 July 2007.

28. Sunday Nation, 23/12/2007. Aspirants Bonny Khalwale (Ikolomani MP) and Nderitu Gachagua (Mathira, in Central Province) were fined after two people were killed in election campaign violence in their constituencies.

29. A total of 118 parties took part in the general elections in which nine candidates ran for president, 2548 aspirants for parlementary seats and 15,332 others sought to capture civic seats.

30. Two weeks to the elections, S. Kivuitu confirmed errors in the printing of ballot papers, with names of some candidates or the symbols of various political parties having been misprinted for 11 constituencies.

31. Daily Nation, 28 December 2007.

32. Daily Nation, 11 January 2008.

33. The Standard, 1 January 2008.

34. Saturday Nation, 5 January 2008.

35. The Standard, 2 January 2008.

36. Evan Gicheru indeed gave the impression that he lacked impartiality, particularly by rushing to swear in $\mathrm{M}$. Kibaki the same evening that the results were announced and before an audience limited to the pro-government circle.

37. On the organization of the judiciary: Y.P. Ghai, J.P.W.B. McAuslan (1970). On corruption within the judicial administration, refer to various reports by the International Commission of Jurists, in particular: B. Sihanya and P. Kichana (2004).

38. The committee was led by High Court judge, Aaron Ringera.

39. Report of the Integrity and Anti-Corruption Committee of the Judiciary of Kenya, Vol. I (The Ringera Report), September 2003, p. 30-31. 
40. The first wave of appointments in 2003 brought on board 16 High Court judges from the Kikuyu ethnic group, from the Mount Kenya region, whereas before the "clean-up" of the judicial administration, the High Court only had three judges from this community. International Commission of Jurists (ICJ), Kenya: Judicial Independence, Corruption and Reform, Geneva, 2005, p. 2-30.

41. Robert F. Kennedy Memorial Center for Human Rights (1992).

42. Articles 68 and 69 of the Constitution spell out the status and powers of the JSC. It has five members, who include the Chief Justice and the Attorney General, and it is responsable for appointing and maintain discipline among members of the judiciary. In reality, it proposes names to the President who then appoints the judges.

43. The matter led to a very strange situation in that following their appointment, the judges were photographed in their official attire leaving the High Court in the company of the Chief Justice. Then they went to State House, where they were to be sworn in by the President, but they waited for over two hours only for the ceremony to be eventually cancelled. Daily Nation, 9 February 2007.

44. According to Article 19 of the National Assembly and Presidential Elections Act (Chapter 7 of the Laws of Kenya), for all elections, petitions should be filed within 28 days after the publication of the resultats in the Kenya Gazette and will be determined by an election bench of 3 judges. The bench's decision can be contested in the Court of Appeal.

45. Following of the December 2002 general elections, 25 petitions were filed. 12 of these were dismissed while 10 were never determined.

46. Election Petition No. 1 of 2003, High Court in Mombasa.

47. During the 27 December 2007, H. Kombe lost his seat to ODM candidate Amason Kingi.

48. The result of the 1992 presidential election was contested through six petitions filed in the High Court. Two of these were filed by K. Matiba, one by Gibotu Imanyara (FORD$\mathrm{K}$ ), one by James Orengo (FORD-K), one by two voters represented by a lawyer and one by John Harun Mwau. All were dismissed on technical grounds.

49. Refer to: D. Throup and C. Hornsby, op. cit., pp. 556-560.

50. In 1997, M. Kibaki came second after garnering 31\% of the vote. On 22 January 1998, he filed a petition in the High Court (Election Petition No. 1 of 1998) to contest the validity of the $D$. arap Moi's reelection as president.

51. In reality, when the seats won by the parties allied to the two grand coalitions were added up, ODM had 102 seats (2 NARC MPs and one UDM MP) and PNU had 75 (the 14 seats won by KANU and those won by the various other parties), and also had the support of the 16 ODM-K MPs.

52. 15 women were elected as opposed to only eight in 2002.

53. Some among the "veterans" were, however, reelected: John Michuki (75), William ole Ntimama (76) and M. Kibaki himself (76).

54. In 2002, D. arap Moi unilaterally hand-picked Uhuru Kenyatta as KANU's candidate in the presidential election.

55. On KANU's decline: D. Anderson, (2003). 
56. Sunday Nation, 30/12/07; Sunday Standard, 30/12/07. The Rift Valley voted in favour of R. Odinga, who garnered $64.6 \%$ of the vote to beat Mwai Kibaki who garnered 33.5\%. Similarly, ODM won 31 out of the region's 49 parliamentary seats

57. N. Biwott was leading figure in the KANU government and Keiyo South MP since 1979. The self-styled "Total Man" was one of the most feared politicians in the Moi regime. He was sacked as minister and arrested under D. arap Moi's orders after he was identified as the key suspect in the assasssination of Foreign Minister Robert Ouko in 1990, until the murder charges were finally withdrawn. His name has also been mentioned in most the scandals of D. arap Moi's 24-years regime, particularly the 1992 and 1997 ethnic clashes, though none of these allegations were ever proven. His name was also mentioned in the Goldenberg financial scandal.

58. Paul Muite, Safina party leader, also failed to secure reelection.

59. This group included several political figures from Central Province like Njenga Karume, Chris Murungaru, Martha Karua, Njeru Ndigwa, David Mwiraria, John Michuki, Amos Kimunya. A number of them lost their parliamentary seats, namely N. Karume (Kiambaa), N. Ndigwa (Manyatta), D. Mwiraria (North Imenti), while others managed to retain theirs: J. Michuki (Kangema), M. Karua (Gichugu), K. Murungi (South Imenti).

60. Nevertheless, M. Awori was an old man. Born in 1927, he was 80 years old when the elections were held.

61. The same thing happened in the Kisii region where S. Nyachae, who had been in Parliament since 1992 and was the apparent local power broker, was defeated by a Narc candidate.

62. M. Mudavadi was elected on an ODM ticket while C. Jirongo won on a Kenya African Democratic Union ticket.

63. In the parliamentary elections, ODM won 18 out of the region's 24 seats while in the presidential poll R. Odinga won with $65.9 \%$ of the vote against M. Kibaki's $32.2 \%$.

64. Ford-K, which had 24 MPs in the $9^{\text {th }}$ Parliament, only managed to retain eight in 2007.

65. On the night of 28 January 2008, ODM MP for Embakasi, Mellitus Mugabe Were was murdered, as well as another ODM MP, David Kimutai Too (Ainamoi constituency), a few days later on 31 January. At the same time, the seat retained by K. Marende on an ODM ticket fell vacant in accordance with the law, which states that the seat of an MP elected to become Speaker of the National Assembly becomes vacant. The loss of these three seats was significant as K. Marende had been elected Speaker with a difference of only four votes (105 compared to 101 garnered by Francis ole Kaparo, the PNU candidate). The three seats fell vacant after the annulment of results of Kilgoris, Wajir North and Kamukunji elections, the PNU camp could again have a majority if it managed to win back the six seats.

66. Most MPs from the "fringe" parties-Kaddu, Pick, Chama Cha Uzalendo (CCU), People's Party Kenya of (PPK), Ford-Asili, National Labour Party, Sisi Kwa Sisi, Democratic Party of Kenya-supported one of the two candidates in the December election but they always considered themselves independent. On the other hand, the DP, Kenda, Ford-K, New Ford-K, Ford-P had conducted campaigns in support of Kibaki but the prospect of nominating their own candidates for the parliamentary and local elections had caused friction with PNU. 
67. Article 40 of the Constitution states that any MP who defects from the party that sponsored him/her to Parliament shall automatically loss his/her seat.

68. In his election, M. Kibaki was sponsored by NARC, a coalition of several political parties, which included the Liberal Democratic Party (LDP) led by R. Odinga. However, within the first three years of NARC government, tension developed between LDP and other members of the alliance. In 2005, during the constitutional referendum, the LDP broke ranks with the Government and called for the rejection of the draft Constitution. After the rejection of the draft Constitution, M. Kibaki sacked his entire cabinet except Vice-President M. Awori and Attorney General A. Wako, then reshuffled it two weeks later. He retained the same ministers except seven of them drawn from the ODM, including R. Odinga and K. Musyoka, who were replaced by pro-government MPs affiliated to NARC (notably Charity Ngilu and M. Kombo), as well as some KANU and Ford-People MPs.

69. About three quarters of the 222 MPs of the ninth Parliament changed their political affiliation between 2002 and the end of 2006, Sunday Nation, 3 December 2006.

70. After M. Kibaki appointed KANU members to join his Governement, one of the party members, Justin Muturi sought to counter this move by introducing an amendment to the National Assembly and Presidential Elections Act, in order to stop any further appointments of opposition MPs to join the Governement without the written approval of his/her party.

71. Paragraph 5 of Article 17 of the National Assembly and Presidential Elections Act stipulates that: "No elected or nominated member of the National Assembly through or as a supporter of a political party (other than the party whose candidate has been elected President) shall be appointed a minister of the Government of Kenya in accordance with Article 16 of the Constitution without the consent of the party that sponsored him/her for election or nominated $\mathrm{him} / \mathrm{her}$ to the National Assembly."

72. The role of the Speaker of the National Assembly is fundamental as he/she who decides which laws, issues and motions to be prioritized. He can also control the number of ex-officio members of the chamber.

73. In the third round of the vote, he obtained 105 votes against 101 obtained by F. ole Kaparo, outgoing Speaker of the National Assembly. Farah Maalim, also an ODM candidate, was elected deputy Speaker.

74. The Vice-President has no real political responsibility, except in the event of a vacancy in the Presidency when he/she can become acting president.

75. For example, Article 23 of the Constitution provides that all executive authority is vested in the President.

76. D. Bourmaud (1988), p. 112.

77. To be elected President, a candidate should not only will the presidential election, but should also be elected MP in his constituency. However, he remains an MP after his election as president, as opposed to the Speaker of the National Assembly, whose parliamentary seat falls vacant after his election to head the August House. During the 2007 general elections, M. Kibaki was sure of winning his seat in Othaya constituency in the heart of Kikuyu land but the situation was less sure for R. Odinga, parliamentary candidate for Lang'ata, a constituency in Nairobi whose population was less homogenous.

78. D. Bourmaud, op. cit., pp. 118-119. 
79. The Standard, 28 February 2008.

\section{AUTHOR}

\section{ANNE CUSSAC}

The author is a PhD candidate at Université Paris 1 and a junior research fellow at IFRA-Nairobi. 